\title{
A CONFIGURAÇÃO MODERNA DO SERTÃO
}

\section{Elder Patrick Maia Alves}

Curso: Mestrado em Sociologia

Data de defesa da tese: 15 de dezembro de 2004

Orientadora: Prof ${ }^{a}$ Dr $^{a}$ Maria Angélica Brasil Gonçalves Madeira

\section{Resumo}

O tema deste trabalho é a formação sócio-histórica de um sentido sociológico inscrito no processo de modernização nacional o sertão. Em sua investigação, necessária para se apreender a longo prazo as interfaces contemporâneas entre cultura e desenvolvimento econômico, dois temas paralelos surgem: 1) a importância sociológica dos bens de consumo simbólicos, neste caso específico a literatura e o cinema; 2) o papel desempenhado por seus produtores e realizadores, os intelectuais e artistas nacionais.

Em face disso, o objetivo central deste trabalho é mostrar como, primeiro, o sertão faz parte do longo processo de formação da autoimagem e do pertencimento nacional-brasileiro; segundo, que, através das vicissitudes do processo de modernização nacional, no qual o processo de significação do sertão se acha imiscuído, o sentido etimológico de sertão foi deslocado para um conteúdo especificamente simbólico-cultural, e nesse movimento se converteu em um monopólio de sentido. O que permite inferir que o sentido de sertão, tal qual o conhecemos hoje através dos registros socioculturais de identificação, é resultado das contingências do processo de modernização nacional, desde sua gênese nos fins do século XIX e início do século XX até os contemporâneos núcleos de produção de sentido em âmbito global. 
514 Resumos das teses e dissertações defendidas no PPG-SOL/UnB

Palavras-chave: sertão, sentido, sociogênese, modernidade, processo, nação, bens, consumo e simbólico. 